ANITA PersKa

Uniwersytet Ekonomiczny, Poznań, Polska

\title{
Aktywność samorządu terytorialnego w budowaniu gospodarki opartej na wiedzy
}

\section{The Activity of Local Government in Building a Knowledge-based Economy}

\begin{abstract}
Streszczenie: W artykule wyjaśnia się pojęcie gospodarki opartej na wiedzy i rolę samorządu terytorialnego w procesie jej budowania. Przyjmuje się, że reorientacja gospodarki przebiega etapami, a regiony w trakcie rozwoju przechodzą od wzrostu surowco- i pracochłonnego przez kapitałochłonny do zaawansowanego technologicznie wzrostu opartego na wiedzy. Gospodarka oparta na wiedzy rozumiana jest jako powstała w wyniku tworzenia, przekazywania i wdrażania wiedzy. Wspieranie nowej gospodarki, w której kluczową rolę odgrywa wiedza, staje się ogromnym wyzwaniem dla samorządów, których celem jest osiągnięcie wysokiego poziomu rozwoju oraz konkurencyjności. Badaniem obejmuje się wybrane jednostki samorządu terytorialnego. Celami artykułu są wyjaśnienie pojęć związanych z samorządem terytorialnym i gospodarką opartą na wiedzy oraz identyfikacja działań jednostek samorządu terytorialnego w zakresie budowania gospodarki opartej na wiedzy. Analizie poddane zostaną przykłady działań jednostek samorządu terytorialnego sprzyjające tworzeniu się i rozprzestrzenianiu wiedzy.
\end{abstract}

Abstract: The article explains the concept of a knowledge-based economy and the role of local government in the process of its construction. It is assumed that the reorientation of an economy takes place in stages and the regions are moving on the path of development from material-intense and labor-intensive growth, through capital-intensive to high-tech knowledge-based growth. A knowledge-based economy is defined as an economy based on the creation, transfer and implementation of knowledge. Support for the new economy, in which knowledge plays a key role, becomes a huge challenge for the government, whose goal is to achieve a high level of development and competitiveness. The article includes a selection of local government units. The purpose of this article is to explain of the concepts of local government and the knowledge-based economy and to identify the activities of local government units in building the knowledge-based economy. The examples of local governments will be analyzed to encourage the creation and spread of knowledge.

Słowa kluczowe: gospodarka oparta na wiedzy; innowacje; Program Operacyjny Kapitał Ludzki; samorząd terytorialny; usługa publiczna

Key words: innovations; knowledge-based economy; local government; the Operational Programme Human Capital; public service 


\section{WPROWADZENIE}

Przedmiotem artykułu jest aktywność samorządu terytorialnego w budowaniu gospodarki opartej na wiedzy (knowledge-based economy). Gospodarka oparta na wiedzy rozumiana jest jako taka, która powstaje w wyniku tworzenia, przekazywania i wdrażania wiedzy (OECD, 1996). W tym znaczeniu wiedza staje się określonym produktem, który napędza rozwój. Wyróżnia się cztery filary gospodarki opartej na wiedzy: otoczenie instytucjonalno-prawne, innowacyjność, infrastrukturę informacyjną oraz edukację i szkolenia, które przyczyniają się do poprawy stanu kapitału ludzkiego. Efektywne wspomaganie rozwoju wiedzy możliwe jest dzięki współpracy pomiędzy różnymi rodzajami podmiotów, wśród których kluczową rolę powinny odgrywać: sektor publiczny (administracja rządowa i samorządowa) i sektor prywatny (przemysł i usługi) oraz sfera badawczo-rozwojowa.

Celem artykułu jest wyjaśnienie pojęć związanych z samorządem terytorialnym i gospodarką opartą na wiedzy oraz identyfikacja działań jednostek samorządu terytorialnego w zakresie budowania gospodarki opartej na wiedzy. Dokonana zostanie analiza wybranych przykładów działań jednostek samorządu terytorialnego sprzyjających tworzeniu się i rozprzestrzenianiu wiedzy w ramach Programu Operacyjnego Kapitał Ludzki na lata 2007$2013^{1}$. Przedstawiony zostanie opis mechanizmu wspierania gospodarki opartej na wiedzy przez samorządy. Zakres czasowy badania to lata 2007-2012, badaniem objęto jednostki samorządu terytorialnego: gminy, powiaty, województwa. Wykorzystane metody obejmują analizę logiczną, dedukcję i analogię oraz jakościowe ujęcie problemu (studia przypadków). Źródłem większości danych empirycznych jest portal http://www.funduszeeuropejskie.gov.pl i powiązane dokumenty.

\section{GOSPODARKA OPARTA NA WIEDZY}

Pojęcie gospodarki opartej na wiedzy jest różnie rozumiane. Zgodnie z definicją OECD (1996) jest to gospodarka oparta na tworzeniu, przekazywaniu i wdrażaniu wiedzy. Według opracowanego wspólnie przez OECD i Bank Światowy raportu, jest to gospodarka, w której „wiedza jest tworzona, przyswajana i wykorzystywana bardziej efektywnie przez przedsiębiorstwa, organizacje, osoby fizyczne i społeczności, sprzyjając szybszemu rozwojowi gospodarczemu” (Dahlman, Andersson, 2000). Bank Światowy podaje, że „,rewolucja wiedzy" oznacza między innymi bliższe powiązania pomiędzy nauką i technologią, większe znaczenie innowacji dla wzrostu gospodarczego i konkurencyjności, wzrastającą rolę edukacji i kształcenia ustawicznego, wzrost inwestycji w sferę niematerialną (R\&D - research and development, oprogramowanie i edukacja) oraz ekspansję ICT (information and communication technologies), która zwiększa międzynarodową współzależność i powiązania (Knowledge for Development, 2012).

\footnotetext{
${ }^{1} \mathrm{~W}$ analizie uwzględniono umowy podpisane do 30.11.2012 r.
} 
Koncepcja gospodarki opartej na wiedzy zakłada, że głównym czynnikiem rozwoju i kształtowania się nowych struktur gospodarki staje się wiedza, a tradycyjne czynniki produkcji: ziemia i zasoby naturalne, praca i kapitał, ustępują jej miejsca (Kukliński, 2003: 53, 203). Regiony przechodzą od wzrostu surowco- i pracochłonnego do zaawansowanego technologicznie wzrostu opartego na innowacjach (Gaczek, 2005: 5). S. Pangsy-Kania podaje, że polityka innowacyjna państwa wynika z jego polityki gospodarczej, będąc jej częścią składową oraz pochodną. Polityka proinnowacyjna powinna sprzyjać tworzeniu: w skali kraju - narodowej zdolności innowacyjnej, w skali regionu - regionalnej zdolności innowacyjnej, a w przedsiębiorstwach - indywidualnej zdolności innowacyjnej (Pangsy-Kania, 2007: 143-144). Polityka innowacyjna wspierająca działania determinujące efektywność narodowego systemu innowacyjnego podlega procesowi przemian, których rezultatem jest coraz większa koncentracja na innowacyjnej polityce regionalnej (Pangsy-Kania, 2007: 174-175). Regionalny system innowacji definiowany jest jako zbiór różnorodnych podmiotów wpływających na procesy innowacyjne oraz powiązań i relacji zachodzących między nimi. Podstawą jego działania jest istnienie powiązań sieciowych oraz środowiska innowacji (Nowakowska, 2011: 69).

Regionalny system innowacji jest tworzony przez:

- podmioty gospodarcze (podsystem produkcyjno-usługowy) - uczestniczą w procesie tworzenia innowacji, transferze technologii, wdrażaniu i komercjalizacji nowych rozwiązań,

- instytucje nauki i sektor B+R (podsystem edukacyjno-naukowo-badawczy) - w jego skład wchodzą różnego rodzaju podmioty badawczo-rozwojowe, jednostki szkolnictwa wyższego i inne instytucje nauki działające w sferze innowacji i transferu technologii,

- instytucje wspierania innowacyjności i transferu technologii (podsystem infrastrukturalny) - tworzone są przez podmioty wspomagające przebieg procesów innowacyjnych, m.in. parki naukowo-technologiczne, inkubatory innowacyjne, centra transferu technologii,

- władze publiczne (lokalne i regionalne) - stanowią ogniwo łączące i pobudzające działania poszczególnych podsystemów przez efektywną politykę innowacyjną określaną w ramach regionalnej strategii innowacji (Nowakowska, 2011: 70).

Regionalny system innowacji stanowi szczególną infrastrukturę dla procesu uczenia się, przyczynia się do współtworzenia dobra klubowego, jakim jest wiedza, i sam staje się dobrem klubowym² (Markowski, 2008: 23). R. Domański podaje, że regionalne systemy innowacji kształtują się łatwiej dzięki wcześniejszym fazom procesu innowacyjnego. Do warunków koniecznych do ich powstania zalicza: kwalifikacje pracowników i menedżerów, zasoby wiedzy ukrytej, tradycje lokalnego współdziałania oraz wewnętrzne i zewnętrzne sieci powiązań. Sieci te podlegają procesowi intensyfikacji wraz z włączeniem się do sieci nowych przedsiębiorstw oraz instytutów badawczych i wyższych uczelni, które tworzą wiedzę skodyfikowaną (Domański, 2005: 25). Ważną rolę odgrywają też wchodzące w skład kształtujących się sieci współpracy administracja rządowa i administracja samorządowa wszystkich poziomów (Domański, Marciniak, 2003). Zadaniem władz publicznych jest stymulowanie wszystkich czynników odpowiedzialnych za rozwój nauki i badań, doskonalenie

${ }^{2}$ Dobra klubowe - dobra, z których może korzystać wiele osób bez szkody dla innych, ale dostęp do nich jest stosunkowo ograniczony i zwykle odpłatny. 
kadr i aplikowanie wysokiej techniki w przedsiębiorstwach regionu uczącego się (Florida, 2000 za Brezdeń, Spallek, 2012).

\section{SAMORZĄD TERYTORIALNY W PROCESIE BUDOWY GOSPODARKI OPARTEJ NA WIEDZY}

Lokalne i regionalne władze publiczne utożsamiane są z jednostkami samorządu terytorialnego odpowiednio na poziomie lokalnym (samorząd gminny i powiatowy) i regionalnym (samorząd województwa). Samorząd powstał w wyniku decentralizacji władzy publicznej i jest odpowiedzialny za realizację zadań publicznych, które zostały określone w poszczególnych ustawach. Ustawy samorządowe szczegółowo wyliczają zakres zadań jednostek samorządu terytorialnego, których celem jest bieżące i nieprzerwane zaspokajanie zbiorowych potrzeb ludności w drodze świadczenia usług powszechnie dostępnych (A. Miszczuk, M. Miszczuk, K. Żuk, 2007: 139). Zadania publiczne realizowane przez samorządy stanowią ofertę usług publicznych świadczonych mieszkańcom. Ustawodawca nie definiuje pojęcia usług, posługując się nim wyłącznie instrumentalnie, wyrażając w tym pojęciu różne treści (w aktach prawnych termin ten może być zatem używany w odmiennych znaczeniach).

Według klasycznej w teorii ekonomii definicji O. Langego usługami są: ,,wszelkie czynności związane bezpośrednio lub pośrednio z zaspokajaniem potrzeb ludzkich, ale nie służące bezpośrednio do wytwarzania" (to, co nie jest wytwarzaniem dóbr materialnych, stanowi działalność usługową). Definicje usług formułowane w naukach ekonomicznych umożliwiają wskazanie dwóch podstawowych desygnatów pojęcia usług: cechą pozwalającą odróżnić świadczenie usług od innych przejawów działalności ekonomicznej jest charakter rezultatu (efektu) wykonanej usługi, z kolei rezultatem wykonania usługi jest odniesienie przez usługobiorcę korzyści, przy czym korzyść ta ma charakter dobra niematerialnego (Chmielnicki, 2005: 35). Usługi publiczne należy traktować jako usługi ogólnospołeczne, niematerialne, nieadresowane, świadczone nieodpłatnie lub odpłatnie na rzecz ogółu społeczeństwa bądź wspólnot samorządowych, których przedmiotem jest dostarczanie dóbr publicznych, charakterystyczną cechą jest brak możliwości wykluczenia jakiegokolwiek członka społeczeństwa (wspólnoty samorządowej) z ich konsumpcji (A. Miszczuk, M. Miszczuk, K. Żuk, 2007: 141). Wśród usług publicznych wyróżnia się usługi administracyjne, społeczne i techniczne.

Usługi administracyjne związane są z wykonywaniem funkcji administracji publicznej m.in. przez wydawanie zezwoleń i decyzji w trybie zgodnym z kodeksem postępowania administracyjnego, wprowadzenie do baz danych informacji przekazanych przez klientów. Usługi społeczne dotyczą głównie utrzymania sieci urządzeń i infrastruktury społecznej i zawierają się w obszarach, takich jak: edukacja publiczna, pomoc społeczna, kultura, ochrona zdrowia, bezpieczeństwo publiczne. Z utrzymaniem obiektów i urządzeń infrastruktury technicznej związane są usługi techniczne. Obejmują one utrzymanie obiektów i urządzeń transportu, gospodarki wodno-ściekowej, gospodarki odpadami, energetyki cieplnej, gospodarki mieszkaniowej. Ponadto usługi te dotyczą utrzymania porządku i czystości w miejscach publicznych (A. Miszczuk, M. Miszczuk, K. Żuk, 2007: 141). 
Jednostki samorządowe mogą wykonywać zadania samodzielnie albo zlecać ich wykonywanie innym podmiotom. Rozwiązania prawne dopuszczają swobodę w wyborze form organizacyjno-prawnych w procesie świadczenia usług publicznych (Wojciechowski, 2012: 167). Świadczenie usług przez samorządy zaspokaja zbiorowe potrzeby wspólnoty. Podstawową jednostką terytorialną jest gmina i to właśnie na nią ustawodawca nałożył realizację zadań publicznych. Określenie „sprawy publiczne o znaczeniu lokalnym” przyjęte w ustawie gminnej jest znacznie pojemniejsze od pojęcia usług publicznych. Można domniemywać, że chodzi o szeroko pojmowany rozwój lokalny (Wojciechowski, 2012: 212). Według badań amerykańskich występuje wyraźna zależność pomiędzy poziomem usług publicznych (obsługa) a rozwojem lokalnej gospodarki: im wyższy poziom usług, tym szybszy rozwój lokalny (Wojciechowski, 2012: 214).

P. Brezdeń i W. Spallek (2012) podają, że rolą władz publicznych jest tworzenie środowiska przyjaznego powstawaniu innowacji przez kreowanie korzystnych warunków: rozwój infrastruktury, budowanie klimatu inwestycyjnego, stymulowanie procesów współpracy oraz profesjonalną administrację. Polskie samorządy wspierają budowę gospodarki opartej na wiedzy, realizując przede wszystkim usługi społeczne w ramach edukacji (ustawowe obligatoryjne zadanie własne gmin - edukacja na poziomie szkół podstawowych i gimnazjów oraz powiatów - edukacja na poziomie szkół średnich) oraz w ramach poprawy jakości kapitału ludzkiego i społecznego. Ponadto samorządy wykazują aktywność w dostosowywaniu infrastruktury teleinformatycznej (np. budowa szerokopasmowego dostępu do Internetu). Szczególnym przypadkiem jest finansowanie instytucji sprzyjających tworzeniu się i rozprzestrzenianiu wiedzy, m.in. parków naukowo-technologicznych, inkubatorów przedsiębiorczości, centrów transferu technologii.

Dla wielu samorządów szansą na podejmowanie działań w ramach budowy gospodarki opartej na wiedzy jest możliwość otrzymania na ich realizację dofinansowania z Unii Europejskiej (UE). W perspektywie finansowej 2007-2013 samorządy mogą ubiegać się o dofinansowanie projektów z Unii Europejskiej w ramach następujących programów: Program Operacyjny Infrastruktura i Środowisko (PO IiŚ), Program Operacyjny Rozwój Polski Wschodniej (PO RPW), Regionalne Programy Operacyjne (RPO) i Program Operacyjny Kapitał Ludzki (PO KL). Samorządy nie mogą zostać beneficjentami Programu Operacyjnego Innowacyjna Gospodarka (PO IG). Składają one wnioski o dofinansowanie konkretnych projektów, wpisujących się w odpowiednie działania/ poddziałania, które oceniane są pod względem spełniania kryteriów formalnych i merytorycznych. W artykule analizie poddano wybrane projekty dotyczące budowania gospodarki opartej na wiedzy, których beneficjentami były jednostki samorządu terytorialnego w ramach Programu Operacyjnego Kapitał Ludzki. 


\section{Program Operacyjny Kapitą Ludzki na lata 2007-2013}

Program Operacyjny Kapitał Ludzki na lata 2007-2013 finansowany jest z Europejskiego Funduszu Społecznego (EFS), a łączna suma środków finansowych przeznaczonych na jego realizację wyniesie ok. 14,43\% całości środków przeznaczonych na realizację programów operacyjnych, tj. 11773409338 EUR. W ramach tej kwoty wielkość alokacji z Europejskiego Funduszu Społecznego wyniesie ok. 10007397937 EUR, a wkład krajowy stanowić będzie ok. 1766011401 EUR. Poziom krajowego współfinansowania został oszacowany na poziomie minimalnym, tj. 15\%. Około 60\% środków Programu zostanie przeznaczonych na wsparcie realizowane przez poszczególne regiony, zaś pozostała kwota (ok. 40\%) będzie wdrażana sektorowo, przez odpowiednie resorty (MRR, 2012: 10). Montaż finansowy w ramach PO KL dotyczący poziomu środków Europejskiego Funduszu Społecznego w stosunku do krajowego współfinansowania wynosi 85\%-15\%. W ramach krajowego współfinansowania środki pochodzić będą z następujących źródeł: budżet państwa, budżet jednostek samorządu terytorialnego oraz inne środki publiczne: Fundusz Pracy, PFRON (MRR, 2012: 11).

Głównym celem Programu Operacyjnego Kapitał Ludzki jest wzrost poziomu zatrudnienia i spójności społecznej. Dążenie do osiągnięcia tego celu następuje m.in. przez aktywizację zawodową, rozwijanie potencjału adaptacyjnego przedsiębiorstw i ich pracowników, podnoszenie poziomu wykształcenia społeczeństwa, zmniejszanie obszarów wykluczenia społecznego oraz wspieranie mechanizmów efektywnego zarządzania w administracji państwowej. Zakłada się, że działania podejmowane w ramach Programu prowadzą do podnoszenia i rozwijania potencjału podmiotów działających w obszarach objętych wsparciem EFS oraz do upowszechniania programów wspierających zatrudnienie i integrację społeczną. Przez dostosowanie polskich przedsiębiorstw do modernizacji gospodarki wspierany jest również rozwój ich potencjału adaptacyjnego, dzieje się tak na skutek inwestycji w doskonalenie zawodowe kadr oraz poprawy jakości działań wspierających rozwój usług szkoleniowo-doradczych w przedsiębiorstwach. Ponadto wspierany jest transfer wiedzy w ramach współpracy pracowników przedsiębiorstw oraz jednostek naukowych (MRR, 2012: 8).

Program Operacyjny Kapitał Ludzki składa się z 10 priorytetów, realizowanych równolegle na poziomie centralnym - priorytety $1-5$ i regionalnym - priorytety $6-10$. W artykule skupiono się na komponencie regionalnym - wsparcie udzielane w jego ramach powinno przyczyniać się do rozwiązywania konkretnych problemów społeczno-gospodarczych w danym województwie (MRR, 2012: 12). Priorytety te obejmują działania związane z rynkiem pracy, promocją integracji społecznej, rozwojem regionalnych kadr gospodarki, zdobywaniem i pogłębianiem wykształcenia i kompetencji w regionach oraz pomocą techniczną ${ }^{3}$. Środki z budżetu państwa na współfinansowanie komponentu regionalnego instytucja zarządzająca przekazuje samorządowi województwa w formie dotacji celowej na wskazany przez samorząd województwa rachunek bankowy na podstawie odrębnej umowy (MRR, 2012: 12). Najwięcej środków publicznych przeznaczonych na finansowanie komponentu

${ }^{3}$ Celem priorytetu „Pomoc techniczna” jest zapewnienie właściwego zarządzania, wdrażania oraz promocji Europejskiego Funduszu Społecznego. 
regionalnego PO KL przeznaczono na priorytety: „Rynek pracy otwarty dla wszystkich”, „Rozwój wykształcenia i kompetencji w regionach”, a następnie „Regionalne kadry gospodarki” i „Promocja integracji społecznej” (MRR, 2012: 12).

Jednostki samorządu terytorialnego w ramach komponentu regionalnego mogą ubiegać się o dofinansowanie projektów w następujących obszarach (Wojewódzki Urząd Pracy w Rzeszowie, 2010):

- aktywizacja zawodowa

- poddziałanie 6.1.1 - wsparcie osób pozostających bez zatrudnienia na regionalnym rynku pracy,

- poddziałanie 7.2.1 - aktywizacja zawodowa i społeczna osób zagrożonych wykluczeniem społecznym,

- ekonomia społeczna

- poddziałanie 7.2.2 - wsparcie ekonomii społecznej,

- podnoszenie i dostosowywanie kwalifikacji i umiejętności osób pracujących do potrzeb regionalnej gospodarki

- poddziałanie 8.1.1 - wspieranie rozwoju kwalifikacji zawodowych i doradztwo dla przedsiębiorstw,

- poddziałanie 8.1.2 - wsparcie procesów adaptacyjnych i modernizacyjnych w regionie, - edukacja

- działanie 9.1 - wyrównywanie szans edukacyjnych i zapewnienie wysokiej jakości usług edukacyjnych świadczonych w systemie oświaty,

- działanie 9.2 - podniesienie atrakcyjności i jakości szkolnictwa zawodowego,

- działanie 9.3 - upowszechnienie formalnego kształcenia ustawicznego w formach szkolnych,

- działanie 9.4 - wysoko wykwalifikowane kadry systemu oświaty,

- przeciwdziałanie marginalizacji obszarów wiejskich przez oddolne inicjatywy lokalne

- działanie 6.3 - działania o charakterze informacyjnym, promocyjnym, szkoleniowym lub doradczym przyczyniające się do poprawy zdolności do zatrudnienia oraz rozwoju usług aktywizacyjnych; rozwój dialogu, partnerstwa publiczno-społecznego i współpracy na rzecz wspierania aktywizacji zawodowej na obszarach wiejskich,

- działanie 7.3 - działania o charakterze informacyjnym, promocyjnym, szkoleniowym lub doradczym przyczyniające się do przeciwdziałania wykluczeniu społecznemu członków społeczności lokalnych zagrożonych wykluczeniem społecznym lub społecznie wykluczonych; rozwój dialogu, partnerstwa publiczno-społecznego i współpracy na poziomie lokalnym na rzecz przeciwdziałania wykluczeniu społecznemu,

- działanie 9.5 - działania o charakterze informacyjnym, promocyjnym, szkoleniowym lub doradczym przyczyniające się do poprawy warunków rozwoju edukacji na obszarach wiejskich; rozwój dialogu, partnerstwa publiczno-społecznego i współpracy na rzecz promowania edukacji na obszarach wiejskich. 
Ponadto w ramach działania 8.2 - transfer wiedzy - wyróżnić należy poddziałanie 8.2.2 Regionalne Strategie Innowacji (projekty systemowe ${ }^{4}$ ). Projekty systemowe realizowane w ramach tego poddziałania mają przyczynić się do rozwoju Regionalnych Strategii Innowacji. Możliwe jest dofinansowanie tworzenia, rozwoju i aktualizacji Regionalnych Strategii Innowacji (RSI) przez realizację studiów, analiz i ekspertyz. Można również uzyskać wsparcie na szkolenia i doradztwo dla podmiotów, które wdrażają RSI. Ponadto projekty dotyczą pomocy przy tworzeniu i rozwijaniu sieci współpracy i wymiany informacji między naukowcami a przedsiębiorstwami w zakresie innowacji i transferu technologii na poziomie regionalnym i lokalnym dzięki kampaniom informacyjnym i rozwojowi systemu komunikacji i wymiany informacji. W ramach tego poddziałania mogą zostać dofinansowane stypendia naukowe i wsparcie towarzyszące dla doktorantów kształcących się na kierunkach uznanych za szczególnie istotne z punktu widzenia rozwoju danego województwa (MRR, 2012: 270; Portal Innowacji, PO KL 8.2.2 Regionalne Strategie Innowacji).

\section{PROJEKTY REALIZOWANE PRZEZ SAMORZĄD GMINNY, POWIATOWY I WOJEWÓDZKI}

Przykładem projektu, którego beneficjentem jest samorząd gminny, jest realizowany w ramach priorytetu 9 „Rozwój wykształcenia i kompetencji w regionach”, działania 9.1 „Wyrównywanie szans edukacyjnych i zapewnienie wysokiej jakości usług edukacyjnych świadczonych w systemie oświaty”, projekt: „Podniesienie jakości usług edukacyjnych w gminie Drawsko Pomorskie". Projekt trwający od 2.01.2012 r. do 28.06.2013 r. był przeznaczony dla gminy Drawsko Pomorskie (wartość ogółem projektu 561030 zł, dofinansowanie UE 476 875,5 zł). Temat projektu dotyczył działań na rzecz zwiększenia udziału w kształceniu i szkoleniu przez całe życie, w szczególności przez przedsięwzięcia na rzecz ograniczenia przedwczesnego porzucania skolaryzacji oraz zminimalizowania dyskryminacji ze względu na płeć. Ponadto prowadzono działania na rzecz poprawy jakości i dostępu do kształcenia i szkoleń na poziomie początkowym, zawodowym i wyższym. Uczestnikami byli uczniowie (395) i nauczyciele szkół podstawowych z gminy, którzy brali udział w dodatkowych zajęciach. Zajęcia odbywały się w następujących blokach: matematyczno-przyrodnicze, polonistyczne, logopedyczne, integracyjne, językowe, artystyczne, ICT, gimnastyka korekcyjna. W ramach projektu przewidziano wyjazdy edukacyjne i zakup pomocy dydaktycznych (Drawskie Strony Internetowe). Inwestowanie w edukację jest działaniem, którego skutki są związane z rozwojem gospodarki opartej na wiedzy przez podniesienie jakości kapitału ludzkiego, co może przyczynić się do rozwoju obszaru, w ramach którego podjęte zostały działania.

\footnotetext{
${ }^{4}$ Zgodnie z przepisami ustawy projekty systemowe polegają na realizacji zadań publicznych przez podmioty działające na podstawie odrębnych przepisów, w zakresie określonym przepisami prawa i dokumentami strategiczno-programowymi przyjętymi przez Radę Ministrów. W ramach PO KL projekty systemowe (niedotyczące pomocy technicznej) mogą być realizowane przez beneficjentów wskazanych w niniejszym dokumencie i/lub właściwym planie działania. Funkcje beneficjenta systemowego może pełnić wskazana odrębna jednostka lub komórka organizacyjna (np. departament) danej instytucji lub urzędu (MRR, 2012: 15).
} 
Samorządy powiatowe realizują projekty samodzielnie albo w formie działań partnerskich z powiatowymi urzędami pracy, czego przykładem jest projekt „,3 kroki do zatrudnienia” w ramach priorytetu 6 ,Rynek pracy otwarty dla wszystkich”, działanie 6.1 „Poprawa dostępu do zatrudnienia oraz wspieranie aktywności zawodowej w regionie”, poddziałanie 6.1.1 „Wsparcie osób pozostających bez zatrudnienia na regionalnym rynku pracy”. Jego beneficjentami są powiat jędrzejowski i Powiatowy Urząd Pracy w Jędrzejowie. Zakres czasowy projektu obejmuje okres od 1.09.2012 r. do 30.04.2014 r. (wartość projektu ogółem: 1126845 zł, dofinansowanie UE 957 818, 25 zł). Celem działania jest wdrażanie aktywnych i prewencyjnych instrumentów rynku pracy, zwłaszcza zwiększenie poziomu aktywności zawodowej 100 osób (60 kobiet i 40 mężczyzn) bezrobotnych zarejestrowanych w Powiatowym Urzędzie Pracy w Jędrzejowie. Uczestnicy projektu korzystają z pośrednictwa zawodowego, odbywają szkolenia i biorą udział w stażach. Grupa 100 osób objęta zostanie poradnictwem indywidualnym, a następnie uczestniczyć będzie w zajęciach grupowych „Przełamywanie barier w poszukiwaniu zatrudnienia”. Zajęcia odbywają się w siedzibie Powiatowego Urzędu Pracy w Jędrzejowie. Uczestnicy projektu mogą skorzystać z następujących szkoleń:

- „Operator koparko-ładowarki kl. III” (202 godziny, 15 osób),

- „Księgowość małych i średnich firm” (150 godzin, 20 osób),

- „Nowoczesny sprzedawca” (150 godzin, 20 osób),

- „Kurs spawania blach i rur spoinami pachwinowymi metodą TIG” (103 godziny, 10 osób),

- „Kurs spawania blach i rur spoinami pachwinowymi metodą MAG” (145 godzin, 15 osób),

- „Carving” (80 godzin, 10 osób),

- „Opiekun osób starszych” (80 godzin, 10 osób).

Po zakończeniu szkoleń grupa 100 osób odbędzie staże trwające do 6 miesięcy. Zakłada się, że przyczyni się to do nabycia praktycznych umiejętności przez uczestników. Ponadto każdy uczestnik projektu jest uprawniony do otrzymywania stypendium i zwrotu kosztów dojazdu za okres odbywania szkolenia oraz stypendium i zwrotu kosztów dojazdu za okres odbywania stażu w wysokości i na zasadach określonych Ustawą z dnia 20 kwietnia 2004 r. o promocji zatrudnienia i instytucjach rynku pracy, Dz.U. z 2008 r. nr 69 poz. 415, z późniejszymi zmianami (Powiatowy Urząd Pracy w Jędrzejowie, projekt pt. „,3 kroki do zatrudnienia"). Wspieranie osób bez zatrudnienia niewątpliwie przyczynia się do rozwoju kapitału ludzkiego danej jednostki terytorialnej. Dzięki szkoleniom i udziałowi w stażach następuje aktywizacja osób pozostających bez pracy, a nabyta przez nie wiedza i umiejętności mogą przyczynić się do poprawy stanu gospodarki jednostki terytorialnej, a dzięki wyspecjalizowaniu w branżach szybkiego rozwoju - mogą decydować o jej przewadze konkurencyjnej względem innych jednostek.

Przykładem projektu realizowanego przez samorząd wojewódzki jest projekt: „Budowa Wielkopolskiego Systemu Innowacji (BWSI)” w ramach priorytetu 8 „Regionalne kadry gospodarki”, działanie 8.2 „Transfer wiedzy”, poddziałanie 8.2.2 „Regionalne Strategie Innowacji”. Priorytet ten jest komplementarny z następującymi funduszami oraz programami operacyjnymi (MRR, 2012: 20): 
- Program Operacyjny Innowacyjna Gospodarka - komplementarność w zakresie innowacyjności, przedsiębiorczości, społeczeństwa informacyjnego, badań i rozwoju,

- Priorytet I Programu INTERREG IVC „Innowacje i gospodarka oparta na wiedzy” komplementarność w zakresie transferu wiedzy,

- 16 Regionalnych Programów Operacyjnych - komplementarność w zakresie przedsiębiorczości, społeczeństwa informacyjnego, badań i rozwoju, wsparcia inwestycji w kształcenie.

Beneficjentem projektu był Departament Gospodarki Urzędu Marszałkowskiego Województwa Wielkopolskiego w Poznaniu, a projekt był realizowany w następujących okresach: 1.01.2008-31.12.2008 r. (wartość projektu ogółem 1200000 zł, dofinansowanie UE 1020000 zł), 1.01.2009-31.12.2009 r. (wartość projektu ogółem 2862515 zł, dofinansowanie UE 2433 137,75 zł), 1.01.2010-31.12.2010 (wartość projektu ogółem 2215 613,68 zł, dofinansowanie UE 1883 271,63 zł), 1.01.2011-31.12.2011 (wartość projektu ogółem 4000000 zł, dofinansowanie UE 3400000 zł). Celem projektu był rozwój potencjału ludzkiego w zakresie badań i innowacji, w szczególności przez organizowanie studiów podyplomowych i szkolenia naukowców oraz współpracę sieciową między uczelniami, ośrodkami badawczymi i przedsiębiorstwami. Był to projekt systemowy o charakterze badawczo-naukowym i promocyjnym, którego celem było: wzmocnienie elementów systemu innowacji, poszerzenie zasobów wiedzy o procesach innowacyjnych w Wielkopolsce, stworzenie wizji Innowacyjnej Wielkopolski, podniesienie świadomości społecznej w zakresie innowacji oraz dostarczenie władzom regionu wiedzy na temat innowacji. Działania realizowane w 2010 r. w ramach projektu systemowego BWSI były kontynuacją przedsięwzięć prowadzonych w 2008 oraz 2009 r. i obejmowały różne obszary (Budowanie Wielkopolskiego Systemu Innowacji).

W ostatnim projekcie zrealizowany został m.in. następny etap wdrożenia koncepcji Wielkopolskiego Centrum Innowacji i Kreatywności (WCIiK), który obejmował badanie realnego potencjału uczelni i innych jednostek. Przeprowadzono również konsultacje środowiskowe dotyczące diagnozy oczekiwań jego potencjalnych użytkowników i zagwarantowano doradztwo eksperckie. W ramach Lokalnego Centrum Innowacji (LCI) w obszarze turystyki w subregionie Północnej Wielkopolski zaplanowano m.in. stworzenie wizualizacji marki produktu obsługiwanego przez LCI, stworzenie pilotażowego portalu oferty turystycznej regionu Północnej Wielkopolski oraz przygotowanie opracowań dotyczących rozwoju turystyki tego regionu z wykorzystaniem LCI. Ponadto wsparte zostało Centrum Doskonałości Kół Zębatych/ Lokalne Platformy Innowacji przez Wielkopolski Klaster Lotniczy oraz samorząd lokalny. Działania w tym zakresie obejmowały organizację warsztatów, spotkań środowiskowych, przygotowanie specjalistycznych opracowań i prowadzenie platformy wymiany informacji. W ramach Akademickiego Inkubatora Przedsiębiorczości (AIP) wdrożono model AIP przez wsparcie inicjatywy „Preinkubator”, nagrodzonej w konkursie Wielkopolski Lider Innowacji. Funkcjonująca Wielkopolska Rada Trzydziestu była organem opiniotwórczym przy Marszałku Województwa Wielkopolskiego. W 2010 r. przeprowadzono proces aktualizacji Regionalnej Strategii Innowacji dla Wielkopolski (RSI), odbyły się konsultacje w subregionach województwa wielkopolskiego oraz powołany został Komitet Sterujący, 
odpowiedzialny za powstanie zaktualizowanego dokumentu RSI. Kolejnym elementem projektu było przeprowadzenie foresightu regionalnego dla Wielkopolski, który obejmował: doradztwo eksperta, pracę Komitetu Sterującego (KS), utworzenie i działanie biura foresightu, obsługę posiedzeń KS, organizację i przeprowadzenie badań scenariuszy foresightu z uwzględnieniem środowisk zdefiniowanych przez ekspertów zespołu ds. foresightu (10 warsztatów), ciągłą komunikację społeczną za pośrednictwem interaktywnego panelu strony internetowej: www.innowacyjna-wielkopolska.pl, raport z badań scenariuszy foresightu przeprowadzonych w 2010 r. oraz organizację konferencji prezentującej zaawansowanie prac w opisanym wyżej zakresie. W ramach Konkursu Wielkopolski Lider Innowacji wyróżniono i wsparto inicjatywy uznane za modelowe ogniwa WSI. Ponadto zorganizowano promocję projektu „Budowa Wielkopolskiego Systemu Innowacji” celem zapoznania różnych środowisk Wielkopolski z postępami w realizacji projektu oraz upowszechnienia wiedzy na temat Wielkopolskiego Systemu Innowacji. Działania te obejmowały produkcję i emisję filmów w mediach regionalnych oraz zakupienie materiałów promocyjnych (Budowa Wielkiego Systemu Innowacji). Wiele działań prowadzonych w ramach projektów przyczyniło się przede wszystkim do podniesienia świadomości w zakresie innowacji i gospodarki opartej na wiedzy. Praktycznym aspektem było dostarczenie władzom województwa informacji o jego potencjale innowacyjnym i stworzenie spójnej wizji rozwoju z zastosowaniem innowacji i designu. Pozytywnym skutkiem prowadzonych działań był dialog społeczny prowadzony z różnym grupami zainteresowanych. Nie ograniczał się on do konsultacji z mieszkańcami stolicy regionu, ale obejmował także spotkania subregionalne, co pomogło w tworzeniu i dyfuzji wiedzy.

\section{ZAKOŃCZENIE}

W artykule wyjaśniono pojęcia związane z samorządem terytorialnym i gospodarką opartą na wiedzy oraz opisano działania jednostek samorządu terytorialnego w zakresie budowania gospodarki opartej na wiedzy. Analizie poddane zostały przykłady działań jednostek samorządu terytorialnego sprzyjające tworzeniu i rozprzestrzenianiu wiedzy, opisano także mechanizm wspierania gospodarki opartej na wiedzy przez samorządy. Samorząd terytorialny ułatwia budowanie tego typu gospodarki, głównie wpływając na poprawę jakości kapitału ludzkiego i społecznego, dostosowywanie infrastruktury teleinformatycznej, co w konsekwencji przyczynia się do wzrostu konkurencyjności i rozwoju jednostek terytorialnych. Aktywność w budowaniu gospodarki opartej na wiedzy może być oceniona na podstawie różnych działań, m.in. podejmowanych w ramach projektów dofinansowanych z Programu Operacyjnego Kapitał Ludzki na lata 2007-2013. Realizowane w ten sposób projekty mieściły się w następujących obszarach: aktywizacja zawodowa, ekonomia społeczna, podnoszenie i dostosowywanie kwalifikacji i umiejętności osób pracujących do potrzeb regionalnej gospodarki, edukacja, przeciwdziałanie marginalizacji obszarów wiejskich 
przez oddolne inicjatywy lokalne. Projekty te uzupełniały podstawowe zadania samorządów na danym poziomie (np. edukacja na poziomie podstawowym - samorząd gminny).

Konieczna jest ewaluacja projektów i ocena wskaźników realizacji projektów. Po zakończeniu perspektywy finansowej 2007-2013 przyszłe badania powinny skoncentrować się na uzupełnieniu informacji przedstawionych w niniejszym artykule o analizę wartości i kierunków rozchodu środków pieniężnych projektów realizowanych przez samorządy, związanych ze wsparciem gospodarki opartej na wiedzy. W ramach kontynuacji tego tematu warto podjąć próbę odpowiedzi na pytanie, czy zrealizowane projekty wpłynęły na rozwój lokalny i regionalny.

\section{Literatura}

Brezdeń, P., Spallek, W. (2012). Kondycja finansowa samorządu terytorialnego w Polsce jako czynnik stymulujący innowacyjność gospodarki. Prace Komisji Geografii Przemystu Polskiego Towarzystwa Geograficznego, 20, 183-197.

Chmielnicki, P. (2005). Świadczenie ustug przez samorząd terytorialny w Polsce. Zagadnienia ustrojowo-prawne. Warszawa: Municipium.

Dahlman, C., Andersson, T. (eds.) (2000). Korea and the Knowledge-based Economy. Making the Transition. Information Society. World Bank Institute, OECD.

Domański, R. (2005). Model ewolucyjnego rozwoju miast i regionów. W: F. Kuźnik (red.), Studia regionalne w Polsce. Teoria, polityka, projektowanie. Katowice: Wydawnictwo Akademii Ekonomicznej w Katowicach.

Domański, R., Marciniak, A. (2003). Sieciowe koncepcje gospodarki miast i regionów. Studia KPZK $P A N, 113$.

Fazlagić, A. (2005). Pomiar niemierzalnego, czyli praca twórcza w perspektywie stu lat tayloryzmu. W: K. Rogoziński (red.), Marketing ustug profesjonalnych. Jakość ustug profesjonalnych. Materiały konferencyjne. T. 2. Poznań: Wydawnictwo Akademii Ekonomicznej.

Gaczek, W.M. (2005). Innowacyjność jako czynnik podnoszenia konkurencyjności gospodarki regionu. W: W.M. Gaczek (red.), Innowacje w rozwoju regionu. Poznań: Wydawnictwo Akademii Ekonomicznej w Poznaniu.

Knowledge for Development (K4D). (2012). Pozyskano z: http://web.worldbank.org/WBSITE/ EXTER NAL/WBI/WBIPRO-GRAMS//0,,contentMDK:20269026 menuPK:461205 pagePK:64156158 piPK:64152884 theSitePK:461198,00.html\#Knowledge (dostęp 27.10.2012).

Kożuch, B., Kożuch, A. (2011). Ustugi publiczne, organizacja i zarządzanie. Kraków: Instytut Spraw Publicznych Uniwersytetu Jagiellońskiego w Krakowie.

Kukliński, A. (red.) (2003). Gospodarka oparta na wiedzy. Perspektywy Banku Światowego. Warszawa: Biuro Banku Światowego w Polsce, Komitet Badań Naukowych.

Markowski, T. (2008). Teoretyczne podstawy rozwoju lokalnego i regionalnego. W: Z. Strzelecki (red.), Gospodarka regionalna i lokalna. Warszawa: Wydawnictwo Naukowe PWN.

Miszczuk, A., Miszczuk, M., Żuk, K. (2007). Gospodarka samorzadu terytorialnego. Warszawa: Wydawnictwo Naukowe PWN.

MRR (2012). Szczegółowy opis priorytetów Programu Operacyjnego Kapitat Ludzki 2007-2013. Warszawa. 
Nowakowska, A. (2011). Regionalny wymiar procesów innowacji. Łódź: Wydawnictwo Uniwersytetu Łódzkiego.

OECD (1996). The Knowledge-Based Economy. Paris.

Pangsy-Kania, S. (2007). Polityka innowacyjna państwa a narodowa strategia konkurencyjnego rozwoju. Gdańsk: Wydawnictwo Uniwersytetu Gdańskiego.

Wojciechowski, E. (2012). Zarządzanie publiczne. Warszawa: Difin.

Wojewódzki Urząd Pracy w Rzeszowie (2010). PO KL 2007-2013 dla Jednostek Samorządu Terytorialnego.

\section{Strony internetowe}

Budowa Wielkopolskiego Systemu Innowacji, http://bwsi-wielkopolska.pl/Page.aspx?v=3\&se=2\&s$\mathrm{se}=9 \&$ aid $=291($ dostęp 12.11.2012)

Drawskie Strony Internetowe, http://www.dsi.net.pl/content/view/5471/101/ (dostęp 12.11.2012)

Portal Innowacji, http://www.pi.gov.pl/Finanse/chapter_94603.asp (dostęp 12.11.2012)

Powiatowy Urząd Pracy w Jędrzejowie http://www.pupjedrzejow.pl/p1/67522/0/Poddzialanie_6.1.1_3 kroki_do_zatrudnienia.html (dostęp 12. 11.2012)

Anita Perska, mgr, Uniwersytet Ekonomiczny w Poznaniu, Katedra Ekonomiki Przestrzennej i Środowiskowej.

Absolwentka jednolitych studiów magisterskich na Wydziale Zarządzania Uniwersytetu Ekonomicznego w Poznaniu (kierunek: gospodarka przestrzenna, specjalność: gospodarka lokalna i globalna), od 2010 r. studentka studiów doktoranckich na tym samym wydziale w Katedrze Ekonomiki Przestrzennej i Środowiskowej. Obszary jej zainteresowań naukowych związane są z zarządzaniem w administracji publicznej, współpracą jednostek samorządu terytorialnego, społeczno-ekonomicznym rozwojem lokalnym i regionalnym, innowacjami i ich rolą we współczesnej gospodarce oraz gospodarką sieciową. Prowadziła zajęcia dydaktyczne m.in. z zarządzania w administracji publicznej, samorządu terytorialnego, marketingu terytorialnego, innowacji i rozwoju gospodarki w przestrzeni.

Anita Perska, graduate at the Faculty of Management at the Poznań University of Economics (specializing in local and global economy), since $2010 \mathrm{PhD}$ doctoral studies at the same Faculty in the Department of Spatial and Environmental Economics. Her research interests are the management of the public administration, the cooperation of local government units, local and regional socio-economic development, innovation and their role in the modern economy and network economy. She has taught students: management in public administration, local self-government, territorial marketing, innovation and economic development in the spatial management.

adres/address: Uniwersytet Ekonomiczny w Poznaniu, Katedra Ekonomiki Przestrzennej

i Środowiskowej

al. Niepodległości 10, 61-875 Poznań, Polska

e-mail: anita.perska@ue.poznan.pl 